Article

\title{
Antifungal Activity of Lactobacillus plantarum ZZUA493 and Its Application to Extend the Shelf Life of Chinese Steamed Buns
}

\author{
Shanshan Zhao ${ }^{1,2} \mathbb{D}$, Xiangmei Hao ${ }^{1,2}$, Fengyuan Yang ${ }^{1,2}$, Yuan Wang ${ }^{1,2}$, Xiaomiao Fan ${ }^{1,2}$ and Yanping Wang ${ }^{1,2, *}$ \\ 1 Henan Key Laboratory of Ion Beam Bio-Engineering, College of Physics, Zhengzhou University, \\ Zhengzhou 450000, China; zsszd@gs.zzu.edu.cn (S.Z.); hxm_dy@163.com (X.H.); yangfy@gs.zzu.edu.cn (F.Y.); \\ wangyuany5@163.com (Y.W.); fanxiaomiao1125@163.com (X.F.) \\ 2 Henan Key Laboratory of Ion Beam Bio-Engineering, School of Agricultural Science, Zhengzhou University, \\ Zhengzhou 450000, China \\ * Correspondence: wyp@zzu.edu.cn; Tel.: +86-0371-67761726
}

check for

updates

Citation: Zhao, S.; Hao, X.; Yang, F.; Wang, Y.; Fan, X.; Wang, Y. Antifungal Activity of Lactobacillus plantarum ZZUA493 and Its Application to Extend the Shelf Life of Chinese Steamed Buns. Foods 2022, 11, 195. https://doi.org/10.3390/ foods11020195

Academic Editor: Dimitra Dimitrellou

Received: 27 November 2021 Accepted: 8 January 2022

Published: 12 January 2022

Publisher's Note: MDPI stays neutral with regard to jurisdictional claims in published maps and institutional affiliations.

Copyright: (C) 2022 by the authors. Licensee MDPI, Basel, Switzerland. This article is an open access article distributed under the terms and conditions of the Creative Commons Attribution (CC BY) license (https:// creativecommons.org/licenses/by/ $4.0 /)$.

\begin{abstract}
Lactic acid bacteria (LAB) can produce many kinds of antifungal substances, which have been widely proven to have antifungal activity. In this study, 359 strains of LAB were screened for antifungal activity against Aspergillus niger (A. niger) using the 96-well microtiter plate method, and three showed strong activity. Of these, ZZUA493 showed a broad-spectrum antifungal ability against A. niger, Aspergillus oryzae, Trichoderma longibrachiatum, Aspergillus flavus and Fusarium graminearum. ZZUA493 was identified as Lactobacillus plantarum. Protease treatment, the removal of hydrogen peroxide with catalase and heat treatment had no effect on the antifungal activity of the cell-free supernatant (CFS) of ZZUA493; organic acids produced by ZZUA493 appeared to have an important role in fungal growth inhibition. The contents of lactic acid, acetic acid and phenyllactic acid in the CFS tended to be stable at $48 \mathrm{~h}$, and amounted to $28.5,15.5$ and $0.075 \mathrm{mg} / \mathrm{mL}$, respectively. In addition, adding ZZUA493, as an ingredient during their preparation, prolonged the shelf life of Chinese steamed buns. Overall, ZZUA493 appears to have good potential as a fungal inhibitor for food preservation.
\end{abstract}

Keywords: lactic acid bacteria; fungi; antifungal activity; Chinese steamed buns

\section{Introduction}

Filamentous fungi such as Aspergilli and Fusaria are major causes of spoilage in foods, crops and livestock forage [1]. Food corruption caused by mold can cause huge economic losses, and the toxin produced by mold will endanger people's health and safety [2]. For the food industry, food safety and hygiene are some of the key issues in its development process. Fungal contamination, which causes the physical and chemical deterioration of food, is often accompanied by detrimental sensory changes, including changes in taste, odor, color and texture, in meat, seafood, dairy products and grains [3]. Many physical or chemical approaches have been taken and implemented to control the growth of filamentous fungi. For example, pulsed light treatment could inactivate Penicillium expansum inoculated in apple juice [4]; the efficacy of UV-C light-emitting diodes and a low-pressure mercury lamp to inactivate Penicillium expansum spores on apple skin was assessed [5]; chlorine dioxide $\left(\mathrm{ClO}_{2}\right)$ fumigation inhibited Penicillium expansum growth and patulin production [6]; natamycin application had a strong inhibitory effect on Botrytis cinerea and Penicillium expansum [7]. However, these approaches are not considered the best solution due to the problems of cost and side effects. In recent years, there has been increased concern about the microbiological safety of various foods. Biological preservatives have become a new favorite in the international food additive market because of their natural origins, high efficiency, non-toxicity or low toxicity and lack of damage to the original flavor of food. 
Bacillus subtilis and Bacillus amyloliquefaciens had significant inhibitory effects on Aspergillus flavus and aflatoxin [8]. Sadiq et al. reviewed the research progress of lactic acid bacteria (LAB) as antifungal and antimycotoxin agents [9]. Rodriguez Assaf et al. isolated several fungi, including Aureobasidium pullulans, Cryptococcus magnus, Metschnikowia pulcherrima and Rhodotorula glutinis, with antifungal activity from fermentation microenvironments and the surfaces of refrigerated grapes [10]. Recent trends in detecting, controlling and detoxifying the patulin mycotoxin were observed using biotechnology methods [11].

LAB, as probiotics, are generally recognized as safe (GRAS) strains [12]. It is widely known that the acidic substances produced by LAB fermentation reduce the $\mathrm{pH}$ value of the environment and cause intracellular acidic stress, resulting in unfavorable conditions for the growth of fungus in food products [13]. These acidic substances, including lactic acid (LA), acetic acid (AA), propionic acid, phenyllactic acid (PLA) and fatty acid, have been proven to have an antifungal ability [14]. In addition to organic acids, some peptides and esters [15] have also been identified as antifungal compounds. LAB are naturally present in many foods and widely used as bio-preservatives because of their antifungal properties. Lan et al. sprayed a certain concentration of LAB fermentation broth on the surfaces of grapes, which could prolong the shelf life of grapes containing Penicillium oxalate for 6 days [16]. Muhialdin et al. reported that the supernatant of the four strains of LAB with antifungal activity that were screened from food could prolong the shelf life of cheese by 19-29 days at $4{ }^{\circ} \mathrm{C}$ and 6-12 days at 20-30 ${ }^{\circ} \mathrm{C}$ [17]. Alireza Sadeghi et al. found that the growth of A. niger on produced bread was also remarkably decreased using controlled sourdough (containing the selected LAB isolate) in comparison with spontaneous sourdough and control bread [18]. Chinese steamed buns (CSB) are a food made from wheat flour and water as raw materials and yeast as the main starter, kneaded into dough, fermented, shaped and steamed after awakening. As the traditional staple food in China, CSB occupy an important position in the population's diet structure. With the acceleration in the pace of the population's lives, the industrialization of staple foods will definitely become a future development trend, and the industrialization of CSB will be an important part of this [19]. However, because CSB are rich in nutrition and have a high water content, they can be easily corrupted by bacteria and mold during storage, and the shelf life is very short; all these factors restrict the development pace of the industrial production of steamed bread [20]. Therefore, screening and identifying the LAB with a high organic acid yield and strong antifungal ability can provide potential biological control agents for prolonging CSB's shelf life.

The objectives of this study were to screen for LAB strains with antifungal activity, and to investigate the antifungal activity and properties of antifungal substances of the selected strain. In addition, the selected strain was applied to CSB to evaluate its effect on shelf life extension.

\section{Materials and Methods}

\subsection{Strains and Growth Conditions}

A total of 359 strains were isolated from alfalfa samples in our laboratory, which were characterized as LAB based on physiological and biochemical experiments [21]. They were cultured on de Man-Rogosa-Sharpe (MRS) agar (Beijing Aoboxing Biotechnology Co., Ltd., Beijing, China) at $30^{\circ} \mathrm{C}$ for $48 \mathrm{~h}$ in an anaerobic environment.

Genomic DNA of fungi (4 strains) were extracted by CTAB (cetyltrimethylammonium ammonium bromide) cleavage, and amplified by the universal primers of fungal ITS (primer sequence ITS1: $5^{\prime}$-TCCGTAGGTGaACCTGCGG-3' , ITS4:5 '-TCCTCCGCTTATTGATATG-3'); the reaction system was $30 \mathrm{uL}$ : Buffer $3 \mu \mathrm{L}$, dNTP $2 \mu \mathrm{L}$, upstream and downstream primers $3 \mu \mathrm{L}$, respectively, DNA template $1 \mu \mathrm{L}, \mathrm{ddH}_{2} \mathrm{O} 17.8 \mu \mathrm{L}, \mathrm{Q} 5 \mathrm{DNA}$ Polymerase $0.2 \mu \mathrm{L}$. The reaction conditions were $95^{\circ} \mathrm{C}$ for $5 \mathrm{~min}, 95^{\circ} \mathrm{C}, 30 \mathrm{~s}, 55^{\circ} \mathrm{C}, 30 \mathrm{~s}, 72{ }^{\circ} \mathrm{C}, 1 \mathrm{~min}, 35$ cycles; finally, $72{ }^{\circ} \mathrm{C}, 10 \mathrm{~min}$. PCR products were detected with $1 \%$ agarose gel, and the target band was cut and recycled and sent to BGI (Beijing Genomics Institute, Beijing, China) for sequencing. The BLAST results were compared with the genomic data available on 
National Center for Biotechnology Information (NCBI) and fungi (4 strains) were identified as Aspergillus niger (A. niger), which was obtained from alfalfa, Aspergillus oryzae (A. oryzae) and Trichoderma longibrachiatum (T. longibrachiatum), which were obtained from CSB, and Aspergillus flavus (A. flavus), which was obtained from oranges (Figure S1). Fusarium graminearum (F. graminearum) was acquired from the Institute of Agricultural Products Processing, Chinese Academy of Agricultural Sciences, and was obtained from cereal. Putrefactive bacteria (Staphylococcus aureus ATCC 29213, Micrococcus luteus ATCC 4698, Bacillus subtilis ATCC 6633, Pseudomonas aeruginosa ATCC 27853, Escherichia coli ATCC 30105, Listeria monocytogenes BAA) were used as indicator bacteria. The fungal and bacterial strains were inoculated on Potato Dextrose Agar (PDA) (potato extract, 3.0 g; glucose, $20.0 \mathrm{~g}$; agar, $14.0 \mathrm{~g} / \mathrm{L}$ ) and Luria-Bertani (LB) agar (yeast extract, $5.0 \mathrm{~g}$; peptone, $10.0 \mathrm{~g}$; sodium chloride, $5.0 \mathrm{~g}$; agar, $15.0 \mathrm{~g} / \mathrm{L}$ ), incubated at $30{ }^{\circ} \mathrm{C}$ for 72 and $48 \mathrm{~h}$, respectively.

\subsection{Preparation of Fungal Spore Suspensions}

The concentrations of fungal spore suspensions were adjusted to approximately $1.42 \times 10^{7} \mathrm{cfu} \mathrm{mL}^{-1}$ with saline $(9 \mathrm{~g} / \mathrm{L} \mathrm{NaCl}$ solution), to achieve an optical density (OD) of 0.6 at $600 \mathrm{~nm}\left(\mathrm{OD}_{600}\right)$. The prepared spore suspensions of fungi were diluted $0,4,16$ and 32 times, for experiments.

\subsection{Preparation of LAB Fermentation Cell-Free Supernatant (CFS)}

After incubation at $30^{\circ} \mathrm{C}$ for $48 \mathrm{~h}$ in MRS broth, the CFS of LAB strains was obtained by centrifugation $\left(8000 \times \mathrm{g}\right.$ for $10 \mathrm{~min}$ at $\left.4{ }^{\circ} \mathrm{C}\right)$, part of which was freeze-dried and re-dissolved to a 10 -fold higher concentration $(10 \times \mathrm{CFS})$.

\subsection{Screening of LAB Strains for Antifungal Properties In Vitro}

\subsubsection{Preliminary Screening}

Microtiter plates (96-well) were used for preliminary screening, as described previously [22], with some modifications. A suspension of spores of A. niger $(100 \mu \mathrm{L})$ and LAB CFS $(100 \mu \mathrm{L})$ or MRS broth $(100 \mu \mathrm{L}$, as a control) that were 4 or 16 times diluted or undiluted was added to sterile 96-well microtiter plates, and then incubated at $30{ }^{\circ} \mathrm{C}$ for $48 \mathrm{~h}$. The absorbance value $\left(\mathrm{OD}_{600}\right)$ at $600 \mathrm{~nm}$ was measured using an enzyme labeling instrument, and the antifungal rate was calculated using Formula (1), which is as follows:

$$
\text { Antifungal rate }(\%)=\left(1-\frac{\mathrm{OD}_{\mathrm{LAB}}}{\mathrm{OD}_{\mathrm{CONTROL}}}\right) \times 100
$$

where $\mathrm{OD}_{\mathrm{LAB}}$ represents the $\mathrm{OD}_{600}$ of mold spores cultured in LAB fermentation supernatant for $48 \mathrm{~h}$; OD $\mathrm{OD}_{\text {control }}$ indicates the $\mathrm{OD}_{600}$ of mold spores cultured in MRS liquid for $48 \mathrm{~h}$.

\subsubsection{Rescreening}

The dual-culture overlay assay [23] was used for the rescreening, with some modifications. Two lines, approximately $2.5 \mathrm{~mm}$ long, were drawn on MRS agar with LAB strains, and then the plates were incubated in an anaerobic environment for 24 and $48 \mathrm{~h}$. The upper layer of agar was poured ( $5 \mathrm{~mL} /$ plate of PDA, containing the 32-times diluted suspension of spores of 4 kinds of fungi, respectively). After solidification, the plates were incubated at $30{ }^{\circ} \mathrm{C}$, and the antifungal activity was observed visually, after 24 and $48 \mathrm{~h}$.

\subsection{Identification of ZZUA493 Strain}

\subsubsection{Morphological, Physiological and Biochemical Tests of LAB}

Morphology and Gram-staining response were examined after $24 \mathrm{~h}$ of incubation on MRS agar. Catalase activity and gas production from glucose were determined. Growth at different temperatures was observed in MRS broth after incubation at 5 and $10{ }^{\circ} \mathrm{C}$ for $14 \mathrm{~d}$, respectively, and at $30,40,45$ and $50{ }^{\circ} \mathrm{C}$ for $7 \mathrm{~d}$. Salt tolerance was determined in MRS broth with $\mathrm{NaCl}$ at 3.0 and $6.5 \%$ for $2 \mathrm{~d}$. Growth of $\mathrm{LAB}$ at different $\mathrm{pH}-3.0,3.5,4.0,4.5$, 
5.0, 5.5, 6.0, 7.0, 8.0, 8.5, 9.0, 9.5 and 10.0-was determined in MRS broth after incubation at $30{ }^{\circ} \mathrm{C}$ for $7 \mathrm{~d}[21]$.

\subsubsection{Drawing of Growth Curve of LAB}

The LAB were cultured in a scribed line; a single colony was selected and added to a triangular flask containing $100 \mathrm{~mL}$ of MRS liquid, placed in a $30{ }^{\circ} \mathrm{C}$ constant temperature incubator, the bacterial suspension was taken every $2 \mathrm{~h}$, and the $\mathrm{OD}_{600}$ and $\mathrm{pH}$ values were measured.

\subsection{3. $16 \mathrm{~S}$ rRNA Gene Sequencing}

The DNA of ZZUA493 was extracted using a Bacteria Gen DNA extraction kit (Jiangsu Cowin Biotech Co.,Ltd., Taizhou, Jiangsu, China), and then it was subjected to a specific polymerase chain reaction (PCR). The sequence of the primer was 27F: AGAGTTTGATCCTGGCTCAG and 1492R: GGYTACCTTGTTACGACTT $\left(5^{\prime}-3^{\prime}\right)$. PCR reaction system ( 2 * Taq MasterMix; forward primer, $10 \mathrm{M}$; reverse primer, $10 \mathrm{M}$; template DNA; RNase-free water) and reaction conditions $\left(94{ }^{\circ} \mathrm{C} 2 \mathrm{~min} ; 94{ }^{\circ} \mathrm{C} 30 \mathrm{~s} ; 55-65{ }^{\circ} \mathrm{C} 30 \mathrm{~s} ; 72{ }^{\circ} \mathrm{C} 30 \mathrm{~s} ; 72{ }^{\circ} \mathrm{C}\right.$ $2 \mathrm{~min} ; 35$ cycles) were followed, according to the manufacturer's instructions. After agarose gel electrophoresis (TAE, $1 \% w / v$ ), the $16 \mathrm{Sr}$ DNA was sequenced by BGI (Beijing Genomics Institute, Beijing, China). In order to determine the genus of the strain selected, sequence splicing was performed by Seqman splicing software, and then the BLAST results were compared with the genomic data available on NCBI.

\subsection{Studies on the Antifungal Activity and Properties of Antifungal Substances of ZZUA493}

\subsubsection{Antifungal Activity of ZZUA493 CFS}

A study on the antifungal activity of CFS was performed as described previously [24]. The CFS of ZZUA493, or $10 \times$ CFS of ZZUA493, or $10 \times$ CFS of ZZUA493 with the pH adjusted to 6.0 , were added at a concentration of $5 \%$ to liquid PDA agar, mixed well and poured into the plates. The CFS and $10 \times$ CFS were replaced with an equivalent volume of MRS to form the control check (CK). After solidification, F. graminearum or A. niger was inoculated onto the plates, and then incubated at $30{ }^{\circ} \mathrm{C}$. The antifungal activity was observed after $3 \mathrm{~d}$.

\subsubsection{Protease Treatment}

The $\mathrm{pH}$ of CFS was adjusted to the optimum value of each enzyme (trypsin, pepsin and proteinase $\mathrm{K}$ ). After incubation at $37^{\circ} \mathrm{C}$ for $2 \mathrm{~h}, 2 \mathrm{mg} / \mathrm{mL}$ of each proteolytic enzyme of CFS was boiled for $5 \mathrm{~min}$ to inactivate the enzymes. After cooling, the $\mathrm{pH}$ of each treatment group was adjusted to the original value (3.8). The CK contained MRS broth with enzymes. Treated CFS or MRS broth $(100 \mu \mathrm{L})$ and fungal spore suspension $(100 \mu \mathrm{L})$ were placed into 96-well plates, and then incubated at $30{ }^{\circ} \mathrm{C}$ for $48 \mathrm{~h}$. The absorbance $\left(\mathrm{OD}_{600}\right)$ was measured by a microplate reader, and the inhibition rate was calculated.

\subsubsection{Hydrogen Peroxide Removal}

Catalase (Mettler-Toledo AG, Greifensee, Switzerland) was used to remove any hydrogen peroxide in the CFS. The procedure was as for the protease treatment above.

\subsubsection{Acid Exclusion}

In order to test the effect of $\mathrm{pH}$ on the antifungal activity, the $\mathrm{pH}$ of CFS was adjusted to 4.5-6.5 with $1 \mathrm{M} \mathrm{NaOH}$ solution. Treated CFS or MRS broth $(100 \mu \mathrm{L})$ and fungal spore suspension $(100 \mu \mathrm{L})$ were placed into 96 -well plates, and then incubated at $30^{\circ} \mathrm{C}$ for $48 \mathrm{~h}$. The absorbance $\left(\mathrm{OD}_{600}\right)$ was measured using a microplate reader, and the inhibition rate was calculated. 


\subsubsection{Heat Treatment}

The CFS was placed in water baths at 60,80 or $100{ }^{\circ} \mathrm{C}$ for $2 \mathrm{~h}$. Treated CFS or MRS broth $(100 \mu \mathrm{L})$ and fungal spore suspension $(100 \mu \mathrm{L})$ were placed into 96 -well plates, and then incubated at $30{ }^{\circ} \mathrm{C}$ for $48 \mathrm{~h}$. The absorbance $\left(\mathrm{OD}_{600}\right)$ was measured using a microplate reader, and the inhibition rate was calculated.

\subsubsection{Determination of Organic Acid Content of ZZUA493 CFS}

LA, AA and PLA in CFS were determined using High-Performance Liquid Chromatography (HPLC), as described previously [25]. After centrifugation $(8000 \times g$ for $10 \mathrm{~min}$ at $\left.4{ }^{\circ} \mathrm{C}\right)$, the CFS was sterilized with a micro filter $(0.22 \mu \mathrm{m}$, JIN TENG) and directly injected into the HPLC system (Waters, Milford, MA, USA), fitted with a Symmetry C18 column $(250 \times 4.6 \mathrm{~mm}, 5 \mu \mathrm{m}$ particle size; Waters $)$. The mobile phase was $0.05 \%$ aqueous TFA (solvent A) and methanol with $0.05 \%$ TFA (solvent $\mathrm{B}$ ). The linear gradient was as follows: $0-20 \mathrm{~min}-10-100 \% \mathrm{~B} ; 20-30 \mathrm{~min}-100 \% \mathrm{~B}$. The flow rate was set to $0.6 \mathrm{~mL} / \mathrm{min}$, column temperature to $55^{\circ} \mathrm{C}$ and a volume of $10 \mu \mathrm{L}$ was injected. Organic acids were detected at a UV wavelength of $210 \mathrm{~nm}$ and quantified by comparison with external standard solutions.

Treated CFS or LA with concentrations of $30 \mathrm{mg} / \mathrm{mL}$ or AA with concentrations of $15 \mathrm{mg} / \mathrm{mL}$ or PLA with concentrations of $0.075 \mathrm{mg} / \mathrm{mL}$ or a mixture of LA, AA and PLA in the same concentration as CFS or MRS broth $(100 \mu \mathrm{L})$ and fungal spore suspension $(100 \mu \mathrm{L})$ were placed into 96 -well plates, and then incubated at $30{ }^{\circ} \mathrm{C}$ for $48 \mathrm{~h}$. The absorbance $\left(\mathrm{OD}_{600}\right)$ was measured by a microplate reader, and the inhibition rate was calculated.

\subsection{Cloning of Genes Associated with the Related of Bacteriocin of ZZUA493}

Rapid PCR amplification: The reported genes encoding bacterin synthesis from Lactobacillus plantarum C11, NC8, V90, J23, J51, WCFS1 and 423 were found from the NCBI database, and specific primers were designed [26] (Table S1). In addition, three other specific primers (Table S1) were designed to validate the presence of pediocin, enterocin and plantaricin for PCR amplification verification [27]. PCR system of each gene: $10 \mu \mathrm{mol} / \mathrm{L}$ upstream and downstream primers of $2 \mu \mathrm{L}$ for each gene; $1 \mu \mathrm{L}$ of a DNA template; $25 \mu \mathrm{L}$ of a Taq enzyme; $\mathrm{ddH}_{2} \mathrm{O}$ was added to make up $50 \mu \mathrm{L}$. Reaction conditions: pre-denaturation at $94{ }^{\circ} \mathrm{C}$ for $3 \mathrm{~min}$. There were 30 cycles of denaturation at $94{ }^{\circ} \mathrm{C}$ for $30 \mathrm{~s}$, annealing at $50-60{ }^{\circ} \mathrm{C}$ for $30 \mathrm{~s}$, extension at $72{ }^{\circ} \mathrm{C}$ for $40 \mathrm{~s}$ and extension at $72{ }^{\circ} \mathrm{C}$ for $10 \mathrm{~min}$. After PCR amplification, $5 \mu \mathrm{L}$ of PCR products was subjected to agarose gel electrophoresis $(1.5 \%$ agarose, $1 \times \mathrm{TAE}, 150 \mathrm{~V})$ for $20 \mathrm{~min}$. A $2000 \mathrm{bp}$ molecular size standard ladder was used. The gel was stained with ethidium bromide and analyzed using a Gel Doc TM XR system (Bio-Rad Co., Ltd., Hercules, CA, USA).

\subsection{Testing of ZZUA493 for Extending the Shelf-Life of CSB}

ZZUA493 was cultured in MRS broth at $30{ }^{\circ} \mathrm{C}$ for $12 \mathrm{~h}$, and then the biomass was collected by cold centrifugation. After pouring off the supernatant, the thalli were washed and resuspended in sterile water to obtain a cell suspension. The suspension was adjusted to an $\mathrm{OD}_{600}$ of $0.5\left(2.31 \times 10^{8} \mathrm{cfu} \mathrm{mL}^{-1}\right)$ before use. To produce sourdough, the cell suspension $(2 \mathrm{~mL})$ was immediately mixed with wheat flour (100 g; from a local supermarket) and water $(100 \mathrm{~mL})$ and incubated at $30{ }^{\circ} \mathrm{C}$ for $14 \mathrm{~h}$. The cell suspension was replaced with sterile water in the CK.

The production process is shown in Figure 1. CSB were produced from a mixture of $150 \mathrm{~g}$ of flour, $100 \mathrm{~g}$ of sourdough, $1 \mathrm{~g}$ of instant dry yeast (Angel Yeast(Yili)Co.,Ltd., Yili, Xinjiang, China) and $50 \mathrm{~mL}$ of water. After stirring, the dough was incubated at room temperature (approximately $22{ }^{\circ} \mathrm{C}$ ) for $5 \mathrm{~h}$. The dough was smoothed with a small amount of flour, and then divided into pieces of 50-55 g. The dough pieces were rolled into balls, incubated in a steamer at room temperature for 30-40 min and then steamed at $100{ }^{\circ} \mathrm{C}$ for 30-35 min. The steamed bread was placed in a clean environment for $2 \mathrm{~h}$ and aired to room temperature. The steamed bread samples of the experimental group and the two control groups were sliced, placed into a sterilized and dry plate, and part of it was placed 
in a clean edible bag. Three parallel procedures were set in each group, and the time was recorded. Photos were taken every day to observe the gap between the experimental group and the control group.

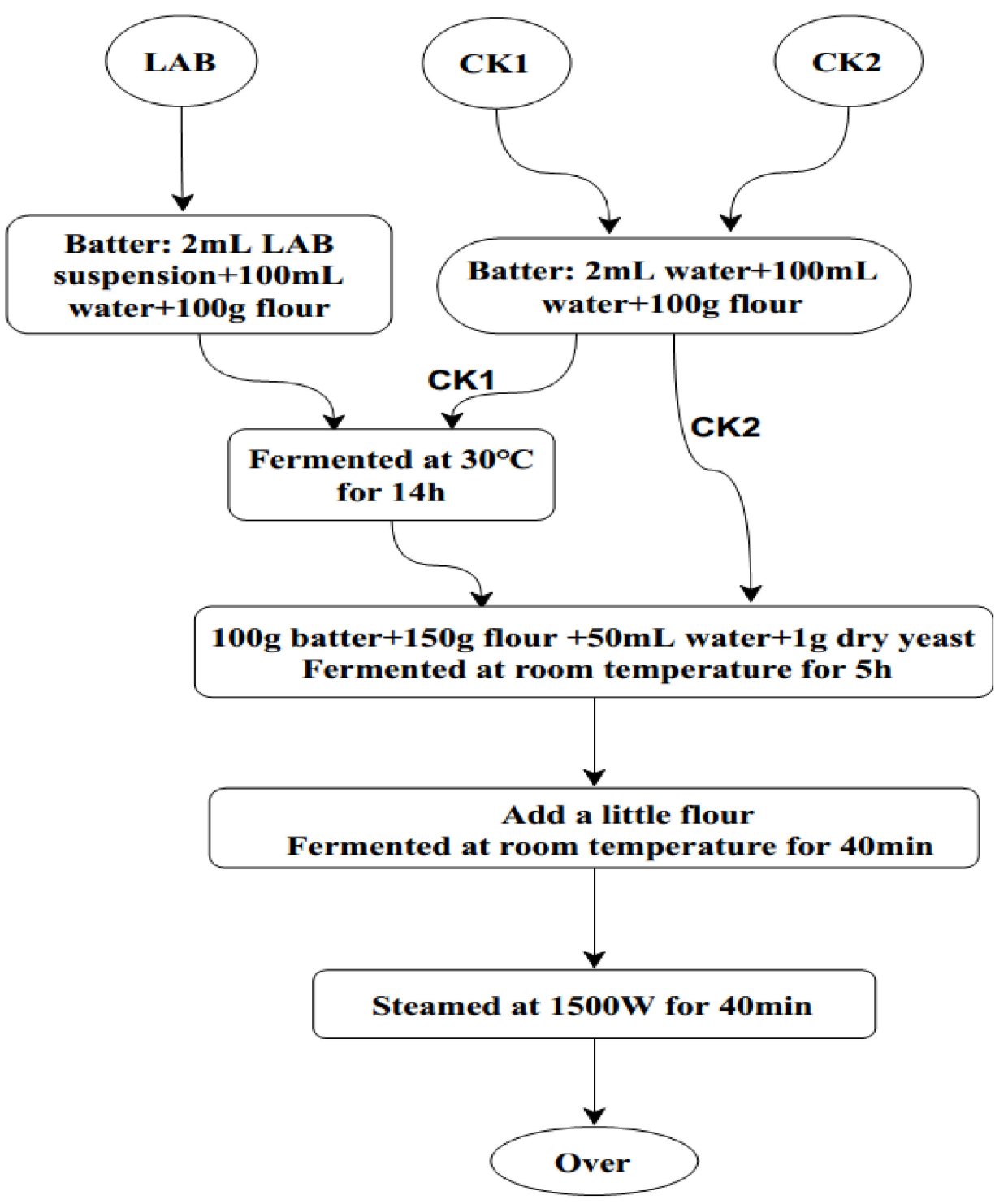

Figure 1. Steps to produce CSB with or without LAB. CSB, Chinese steamed buns; LAB, lactic acid bacteria, Batter: $2 \mathrm{~mL}$ ZZUA493 suspension $+100 \mathrm{~mL}$ water $+100 \mathrm{~g}$ flour fermented at $30{ }^{\circ} \mathrm{C}$ for $14 \mathrm{~h}$; CK1, Batter: $2 \mathrm{~mL}$ water $+100 \mathrm{~mL}$ water $+100 \mathrm{~g}$ flour fermented at $30^{\circ} \mathrm{C}$ for $14 \mathrm{~h}$ control; CK2, Batter: $2 \mathrm{~mL}$ water $+100 \mathrm{~mL}$ water $+100 \mathrm{~g}$ flour unfermented control.

\subsection{Statistical Analysis}

Biomass was calculated as the number of colony-forming units per $\mathrm{mL}$ of sample $\left(\mathrm{cfu} \mathrm{mL} \mathrm{m}^{-1}\right)$. All the experiments were conducted in triplicate. Data obtained from microbiology were analyzed using ANOVA and displayed using Origin drawing software. The results were recognized as statistically significant at $p<0.05$.

\section{Results and Discussion}

\subsection{Screening of LAB Strains for Antifungal Activity}

The antifungal activity of LAB was screened from 359 strains using the 96-well microtiter plate method. Among them, 148 strains had antifungal activity against the spore suspension diluted 16 times $\left(8.88 \times 10^{5} \mathrm{cfu} \mathrm{mL}^{-1}\right)$. At the second round, 71 of the 
148 strains were selected for the antifungal activity against the spore suspension diluted four times $\left(3.55 \times 10^{6} \mathrm{cfu} \mathrm{mL}^{-1}\right)$. In the third round (Figure 2A), three strains (ZZUA493, ZZUA570 and ZZUA606) had antifungal activity against the undiluted spore suspension $\left(1.42 \times 10^{7} \mathrm{cfu} \mathrm{mL}^{-1}\right)$ (Figure $\left.2 \mathrm{~B}\right)$. In this study, screening with microtiter plates was found to be simple and convenient for massive screening, while the dual-culture overlay assay could accurately compare the relative activities of ZZUA493, ZZUA570 and ZZUA606. To characterize the antifungal activity of the three best LAB strains in more detail, the dual-culture overlay assay was used with A. niger, A. oryzae, T. longibrachiatum and A. flavus (Figure 2C); all three LAB strains exhibited clear regions indicating an inhibition of fungal growth, with ZZUA493 having the largest clear regions and ZZUA606 the smallest. The inhibition rate of three strains of LAB on four fungi is shown in Figure 2D,E. The antibacterial activity of ZZUA493 on four fungi was significantly higher than that of ZZUA570 and ZZUA606 ( $p<0.05)$. Therefore, ZZUA493 had the strongest antifungal activity and was selected for further experiments. Moreover, the selection of fungal targets is also important because they should represent the occurrence of pollutants and biodiversity [28]. In this study, four fungal targets were selected from contaminated products; of these, $A$. niger was the most sensitive, and $A$. flavus was the least sensitive to the antifungal activity of LAB strains; therefore, $A$. niger was selected as the fungal target for the subsequent experiments.

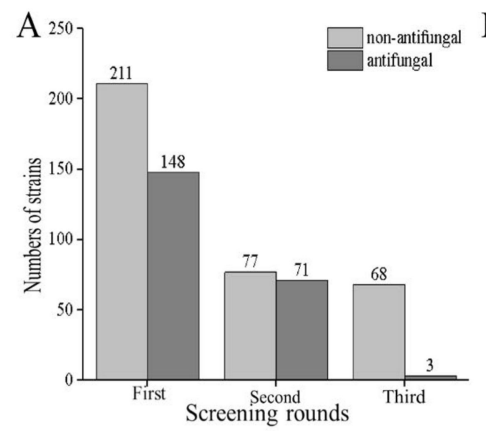

C

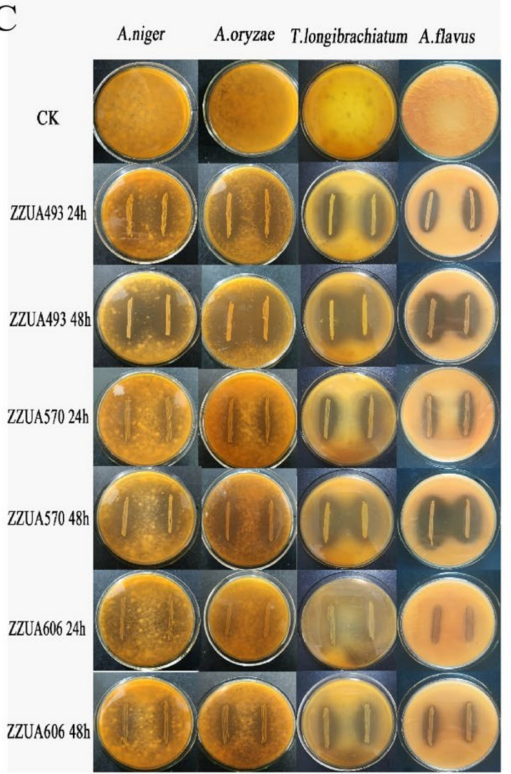

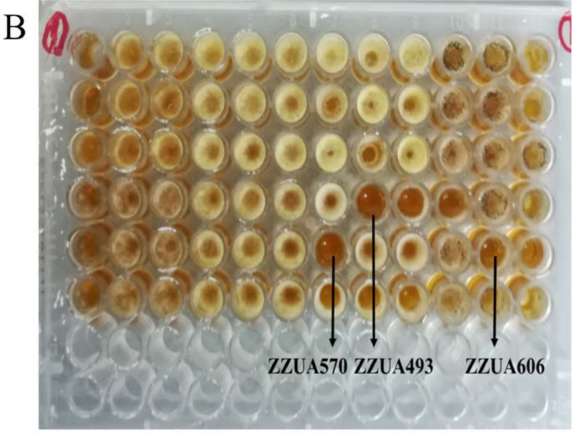

$\mathrm{D}$

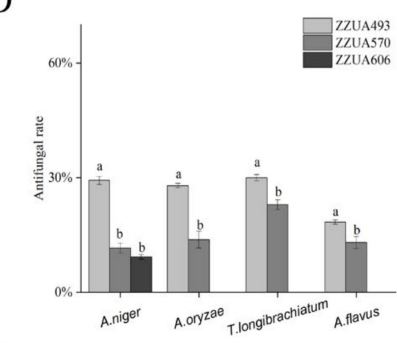

E

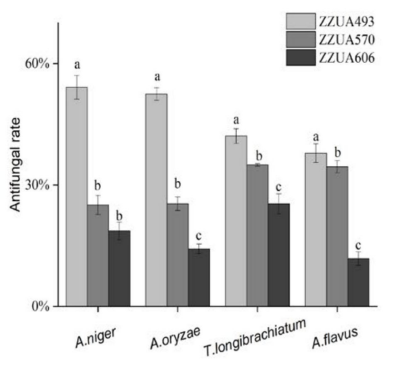

Figure 2. Detection of antifungal ability by 96-well microtiter plate and dual-culture overlay assay method. The strains with antifungal ability against $A$. niger screened out in three rounds by 96-well microtiter plate method (A); 96-well plate method was used to detect the antibacterial activity of 71 LAB 
strains against $A$. niger (B); The antifungal activity of ZZUA493, ZZUA570 and ZZUA606 against 4 kinds of fungi (A. niger, A. oryzae, T. longibrachiatum and A. flavus), tested by dual-culture overlay assay method (C); Antifungal rate of ZZUA493, ZZUA570 and ZZUA606 against 4 kinds of fungi after $24 \mathrm{~h}$ incubation (D); Antifungal rate of ZZUA493, ZZUA570 and ZZUA606 against 4 kinds of fungi after $48 \mathrm{~h}$ incubation (E). Values with different superscript lowercase letters show significant differences among treatments of ZZUA493, ZZUA570 and ZZUA606 $(p<0.05)$. CK, no LAB control; A. niger, Aspergillus niger; A. oryzae, Aspergillus oryzae; T. longibrachiatum, Trichoderma longibrachiatum; A. flavus, Aspergillus flavus.

\subsection{Morphological, Physiological and Biochemical Properties and Molecular Identification of ZZUA493}

The physiochemical test showed that ZZUA493 was Gram-positive, catalase-negative, rod-shaped and of homo-type fermentation (Figure 3A,B), which confirmed that it belonged to Lactobacillus. The growth of ZZUA493 was not affected under the condition of salt at 3 and $6.5 \%$. In the presence of salt, salt-tolerant microorganisms can reproduce, while other salt-sensitive microorganisms are repressed [29]. In the current study, ZZUA493 could grow in $6.5 \%$ salted MRS broth, and this laid the foundation for the application of ZZUA493 in a high-salt environment. After incubation at different temperatures (Table 1), ZZUA493 was weaker at 5 and $50{ }^{\circ} \mathrm{C}$ than $10-45^{\circ} \mathrm{C}$, with good heat and cold resistance, which increased the possibility of high-temperature and low-temperature fermentation. Moreover, under the condition of $\mathrm{pH} 3.0-10.0$, the growth was not affected. The growth curve of ZZUA493 was measured within $24 \mathrm{~h}$. As shown in Figure 3C, ZZUA493 was in the logarithmic growth phase at $4-8 \mathrm{~h}$ and in the slow growth phase after $12 \mathrm{~h}$. It can be seen that the strain grew rapidly and reached the stable growth phase within $12 \mathrm{~h}$. In addition, at 4-8 h, the pH value of the fermentation broth of the strain declined rapidly, during which organic acids could be produced and accumulated rapidly. The $\mathrm{pH}$ changed slowly after $12 \mathrm{~h}$. It is well known that LAB can produce organic acids, and the presence of organic acids will reduce the environmental $\mathrm{pH}$ and inhibit the growth of spoilage bacteria. Furthermore, ZZUA493 had strong antibacterial activity on Staphylococcus aureus, Bacillus subtilis, Micrococcus luteus, Pseudomonas aeruginosa, Escherichia coli and Listeria monocytogenes (Table S2). The 16Sr RNA gene sequence analysis (Figure 3D) showed that ZZUA493 belonged to L. plantarum, with a homology of $99.93 \%$. The 16Sr RNA gene sequence of strain ZZUA493 has been deposited in the GenBank repository with accession number OM037031.

Table 1. The physiological and biochemical characteristics of ZZUA493.

\begin{tabular}{|c|c|c|c|c|c|c|c|c|c|c|c|c|}
\hline \multirow{2}{*}{$\begin{array}{l}\text { Gram } \\
\text { Stain }\end{array}$} & \multirow{2}{*}{ Shape } & \multirow{2}{*}{$\begin{array}{c}\text { Fermentation } \\
\text { Type }\end{array}$} & \multicolumn{6}{|c|}{ Growth at Temperature $\left({ }^{\circ} \mathrm{C}\right)$} & \multicolumn{2}{|c|}{$\begin{array}{c}\text { Growth in } \mathrm{NaCl} \\
(w / v \%)\end{array}$} & \multirow{2}{*}{$\begin{array}{l}\text { Gas from } \\
\text { Glucose }\end{array}$} & \multirow{2}{*}{ Catalase } \\
\hline & & & 4 & 10 & 20 & 30 & 40 & 50 & 3.0 & 6.5 & & \\
\hline+ & Rod & Homo & $\mathrm{w}$ & + & + & + & + & $\mathrm{w}$ & + & + & - & - \\
\hline \multicolumn{13}{|c|}{ Growth at $\mathrm{pH}$} \\
\hline 3.0 & 3.5 & 4.0 & 4.5 & 5.0 & 5.5 & 6.0 & 7.0 & 8.0 & 8.5 & 9.0 & 9.5 & 10 \\
\hline+ & + & + & + & + & ++ & ++ & + & + & + & + & + & + \\
\hline
\end{tabular}

Notes: ++, Very good growth; +, Good growth; w, Weak growth; -, No growth. 
A

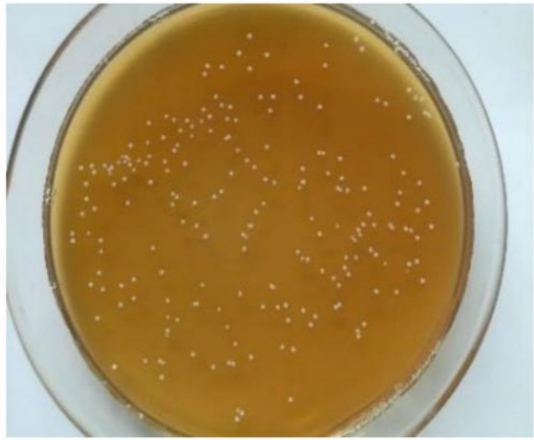

B

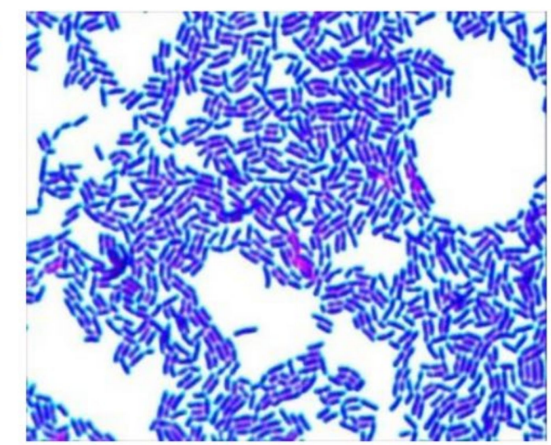

$\mathrm{C}$

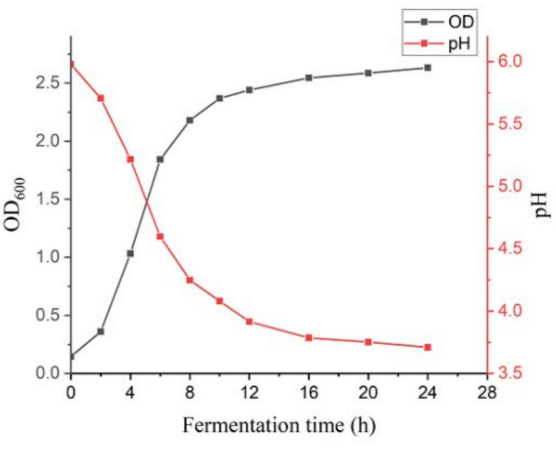

$\mathrm{D}$
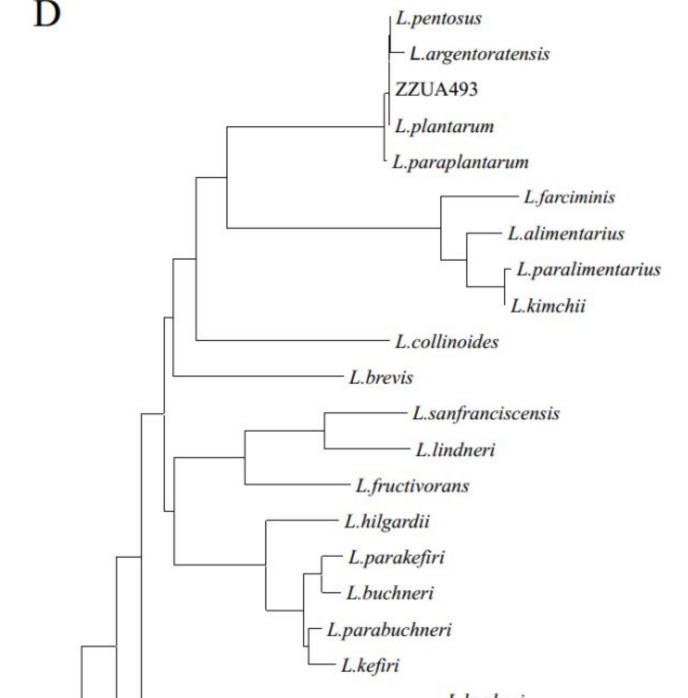

Figure 3. Identification of ZZUA493 strain. Colony morphology (A); gram staining (B); growth and pH change curve of ZZUA493 (C); phylogenetic tree obtained from 16Sr RNA gene sequence analysis, giving the genus of ZZUA493; the tree was generated by the neighbor-joining method and the bar shows $1 \%$ sequence divergence $(\mathbf{D})$.

\subsection{Studies on Antifungal Activity and Properties of Antifungal Substances of ZZUA493}

In this study, it was found that ZZUA493 had obvious inhibitory regions against A. niger, A. oryzae, T. longibrachiatum and A. flavus using the double-layer plate scribing method (Figure 2C), which indicated that ZZUA493 had broad-spectrum antibacterial activity. The fungal spoilage of grain is often caused by Fusarium spp. and results in serious risks to food safety and human health [30]. The high toxicity and carcinogenicity of Fusarium spp. mean that inhibiting the growth is critical for effective grain preservation in storage. The addition of the CFS of ZZUA493 showed clear inhibition against $F$. graminearum but low inhibition against $A$. niger (Figure 4 ), which meant that $F$. graminearum was more sensitive to the CFS. However, the antifungal activity of ZZUA493 against $A$. niger in the previous results was the opposite, which may have been due to the low content of antifungal substances in the $10 \times$ CFS. The metabolites produced by LAB in original and neutralized CFS showed various degrees of antifungal activity. A 10-fold-concentrated culture filtrate of L. plantarum completely inhibited Eurotium repens, Eurotium rubrum and Penicillium corylophilum [31]. In this study, F. graminearum did not grow at all on the plate containing $10 \times \mathrm{CFS}$. When the $\mathrm{pH}$ of the $10 \times \mathrm{CFS}$ was adjusted to 6.0 , the $\mathrm{CFS}$ 
showed no antifungal activity compared with the CFS that was not neutralized. In a previous report, the antifungal activity of the CFS, after adjustment to $\mathrm{pH} 7.0$, was no better than blank growth medium [32], which is consistent with our results. Therefore, it appeared that either organic acids themselves inhibited the growth of fungi, or the acidic environment produced by the organic acids may be conducive to the antifungal activity of other antifungal substances.

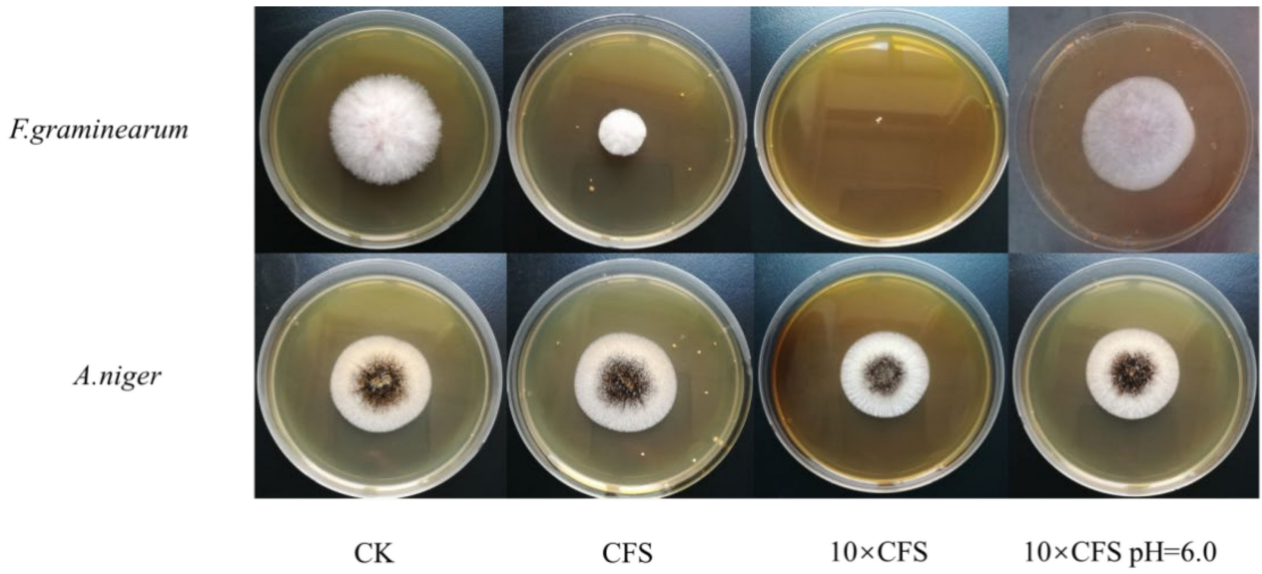

Figure 4. Antifungal effects of the concentrated culture filtrate of ZZUA493 against F.graminearum and A. niger. F. graminearum, Fusarium graminearum; A. niger, Aspergillus niger; CK, no LAB CFS control; $\mathrm{CFS}$, cell-free supernatant; $10 \times \mathrm{CFS}, 10$-fold-concentrated cell-free supernatant; $10 \times \mathrm{CFS} \mathrm{pH}=6.0$, the $\mathrm{pH}$ of $10 \times \mathrm{CFS}$ was adjusted to 6.0 .

LAB can produce many kinds of antifungal substances in the process of growth, such as organic acids, proteins and peptides. To characterize the antifungal substances of ZZUA493, the CFS was treated with protease enzymes, hydrogen peroxide removal, heat treatment and acid neutralization experiments (Figure 5). Protease treatment, the removal of hydrogen peroxide with catalase and heat treatment had no effect on the antifungal activity of the CFS ( $p>0.05)$, which suggested that there were other antifungal substances in addition to enzymes, proteins and hydrogen peroxide. However, when the $\mathrm{pH}$ of the CFS was adjusted to six, the fungal growth inhibition was reduced significantly $(p<0.05)$. When the $\mathrm{pH}$ of the fermentation supernatant was adjusted to near neutral, the antibacterial activity of the treated fermentation supernatant decreased and was significantly lower than that of the untreated fermentation supernatant $(p<0.05)$, indicating that the acidic substances played an important role in the antibacterial activity of ZZUA493. In a previous report, the antifungal activity of the LAB fermentation supernatant, after the $\mathrm{pH}$ was adjusted to 7.0, was not different from that of the control group [32], which was consistent with our results. Guimaraes et al. reported similar results for Lactobacillus plantarum strains [25]. Therefore, it is speculated that the organic acids in the CFS of ZZUA493 play a key role in inhibiting fungi.

With the deepening of research, more and more scholars have begun to explore the exact substances of LAB that have antifungal activity. Corsetti A et al. reported that Lactobacillus Sanfrancisco CB1 from sourdough could inhibit Fusarium, Penicillium, Aspergillus and Monilia and the antibacterial substances were identified as formic acid, AA, propionic acid, butyric acid, n-valeric acid and hexanoic acid [14]. Fernandez A et al. reported that Lactobacillus rhamnosus A238 alone or in combination with Bifidobacterium animalis subsp. lactis A026 inhibited mold growth for at least 21 days at $6{ }^{\circ} \mathrm{C}$; its inhibitory substances were LA, AA, PLA and 4-hydroxy-phenylenetic acid [33]. Prema P et al. found that the main antibacterial substance of Lactobacillus plantarum from silage was PLA [34]. Quattrini et al. found that L. plantarum strain ITEM 17215 showed a strong inhibitory ability towards fungal growth and was able to produce 1, 2-Dihydroxybenzene benzene, benzoic acid, P-hydroxyphenylenik acid and PLA, and the addition of phenylalanine and 
phenylpyruvate to the growth medium further increased the concentration of PLA [35]. PLA has the strongest antifungal activity compared with the same concentration of LA, hydroxyphenyllactic acid and indole LA [25]. In this study, HPLC was used to detect the contents of LA, AA and PLA in the supernatant of ZZUA493 after $48 \mathrm{~h}$ fermentation (Figure 6A). As can be seen from the figure, the contents of LA, AA and PLA tended to be stable after $48 \mathrm{~h}$ of fermentation, amounting to $28.5,15.5$ and $0.075 \mathrm{mg} / \mathrm{mL}$, respectively. The antifungal activities of LA, AA and PLA were compared with those of the CFS fermented for $48 \mathrm{~h}$ by ZZUA493 alone or in mixture, and the results are shown in Figure 6B. For LA, when the concentration was $30 \mathrm{mg} / \mathrm{mL}$, the antifungal rate reached $65.06 \%$. For AA, the antifungal rate was $66.94 \%$ when the concentration was $15 \mathrm{mg} / \mathrm{mL}$, while, for PLA, the antifungal rate was $21.15 \%$ when the concentration was $0.075 \mathrm{mg} / \mathrm{mL}$. When the three acids were mixed together, the antifungal rate was $84.74 \%$, which was not significantly different from that of the CFS fermented for $48 \mathrm{~h}$ by ZZUA493. The results showed that LA, AA and PLA were the main antifungal substances in the CFS of ZZUA493.

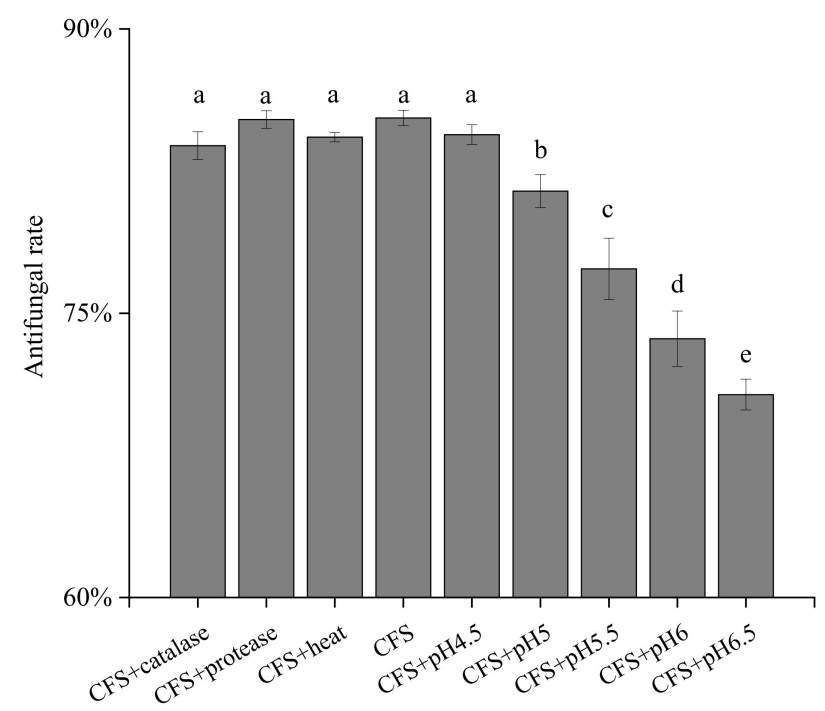

Figure 5. The antifungal rate of CFS after different treatments in 96-well microtiter plate method. Values with different superscript lowercase letters show significant differences among treatments $(p<0.05)$. CFS, cell-free supernatant.

A

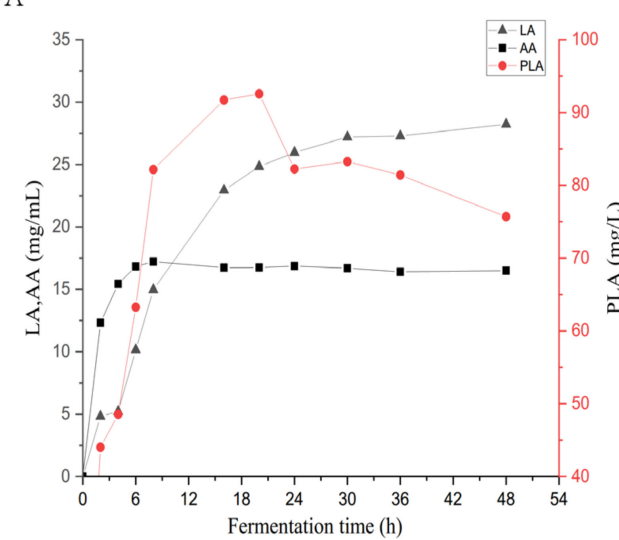

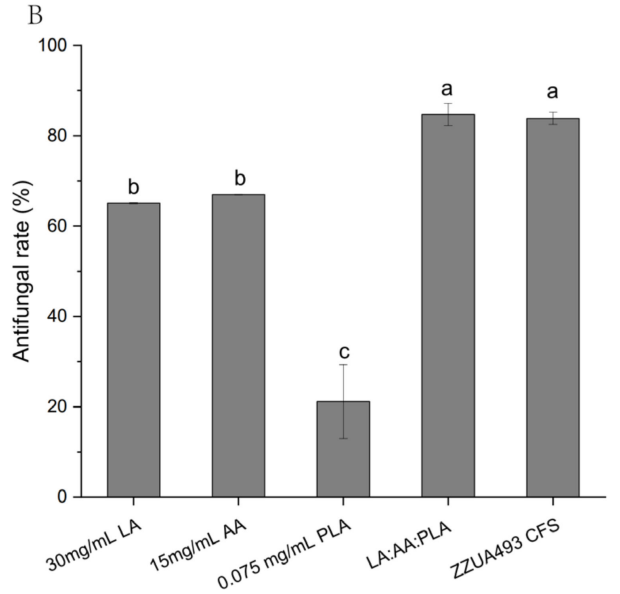

Figure 6. The organic acid production curve of ZZUA493 (A). The antifungal rate of LA, AA, PLA and their mixtures and CFS (B). Values with different superscript lowercase letters show significant differences among treatments $(p<0.05)$. LA, lactic acid; AA, acetic acid; PLA, phenyllactic acids. LA: AA: PLA, the mixtures of $30 \mathrm{mg} / \mathrm{mL} \mathrm{LA}, 15 \mathrm{mg} / \mathrm{mL}$ AA and $0.075 \mathrm{mg} / \mathrm{mL}$ PLA; CFS, cell-free supernatant. 
Besides the acid produced by LAB, bacteriocin, as a safe and effective bacteriostatic substance, has an important prospective application. Bacteriocin is a kind of peptide or precursor peptide with antibacterial activity that is synthesized by bacteria through ribosomes after being stimulated by an external environment or growing to a certain concentration during their growth and metabolism [36]. Lavermicocca P et al. found that the growth of $A$. niger in bread produced by fermentation with $L b$. Plantarum $21 \mathrm{~B}$ that produces PLA was delayed by 7 days, and, in addition to organic acids and PLA, cyclic dipeptides also inhibit the growth of fungi to a certain extent, thus playing an important role in extending the shelf life of bread [31]. Saugar et al. found that the sequence of 11 amino acids located in the n-terminal $\alpha$-helix region of cecropin derivatives was related to antifungal activity [37]. Lee et al. found that, after the fungi were treated with antimicrobial peptides, holes were formed in the membranes of the fungi [38]. With the continuous enrichment of bioinformation such as coding genes, the PCR rapid identification method for screening bacteriocin-producing LAB not only saves a lot of time and workload, but also significantly improves the accuracy [39]. Li et al. quickly detected class IIa bacteriocinproducing LAB with this method [27]. Macwana et al. discovered LAB producing three new bacteriocins based on the PCR method [40]. In order to verify the presence of bacteriocin in ZZUA493, the total DNA of ZZUA493 was used as the template and 13 pairs of bacteriocinrelated gene-specific primers were used for PCR amplification. As shown in Figure 7, both $p \ln W, p \ln S$ and ped could be amplified into a single band, which was consistent with the expected fragment size. The $p \ln W$ gene encodes a membrane protein, the $p \ln S$ gene is located on the transport operon and is responsible for bacteriocin secretion [41], and the ped gene is a gene related to Pediocin, which is widely studied at present [27]. The reports above show that these three genes play important roles in the process of bacteriocin synthesis.

\subsection{Effect of ZZUA493 on the Shelf-Life of CSB}

Cereal-based fermented products are an important, low-cost source of human nutrition, because of their content of protein, carbohydrates, dietary fibers and trace elements [42]. CSB play an important role in Chinese people's daily lives and provide an important dietary source of carbohydrates. Sourdough (i.e., lactic) fermentation can impart a desirable taste and nutritional properties and protects bread from fungal spoilage when LAB with antifungal activity are used, which can reduce the need for chemical preservatives [43]. ZZUA493 did not inhibit the growth of angel yeast in the dual-culture overlay assay method (Figure S2); therefore, a suspension of ZZUA493 was added to flour in order to prepare sourdough. After the sourdough fermentation, the $\mathrm{pH}$ was reduced to 4.6, while the $\mathrm{pH}$ of the control dough without ZZUA493 (CK) was 6.0. Adding LAB can impart an acidic taste to the dough and could also produce aromatic compounds, because of the proteolytic and lipolytic activities in LAB [44]. These substances contribute to the particular flavor of the sourdough. After steaming, our sourdough buns had a sour aroma, while the CK buns had an unpleasant smell. The sourdough buns had a soft mouthfeel, which was more palatable than the CK. In this experiment, compared with the CK group, the addition of acid dough composed of ZZUA493 and yeast significantly delayed the growth rate of the mold on the surface of the CSB (Figure 8), indicating that ZZUA493 has the potential to prolong the shelf life of CSB and then serve as a biological preservative. 

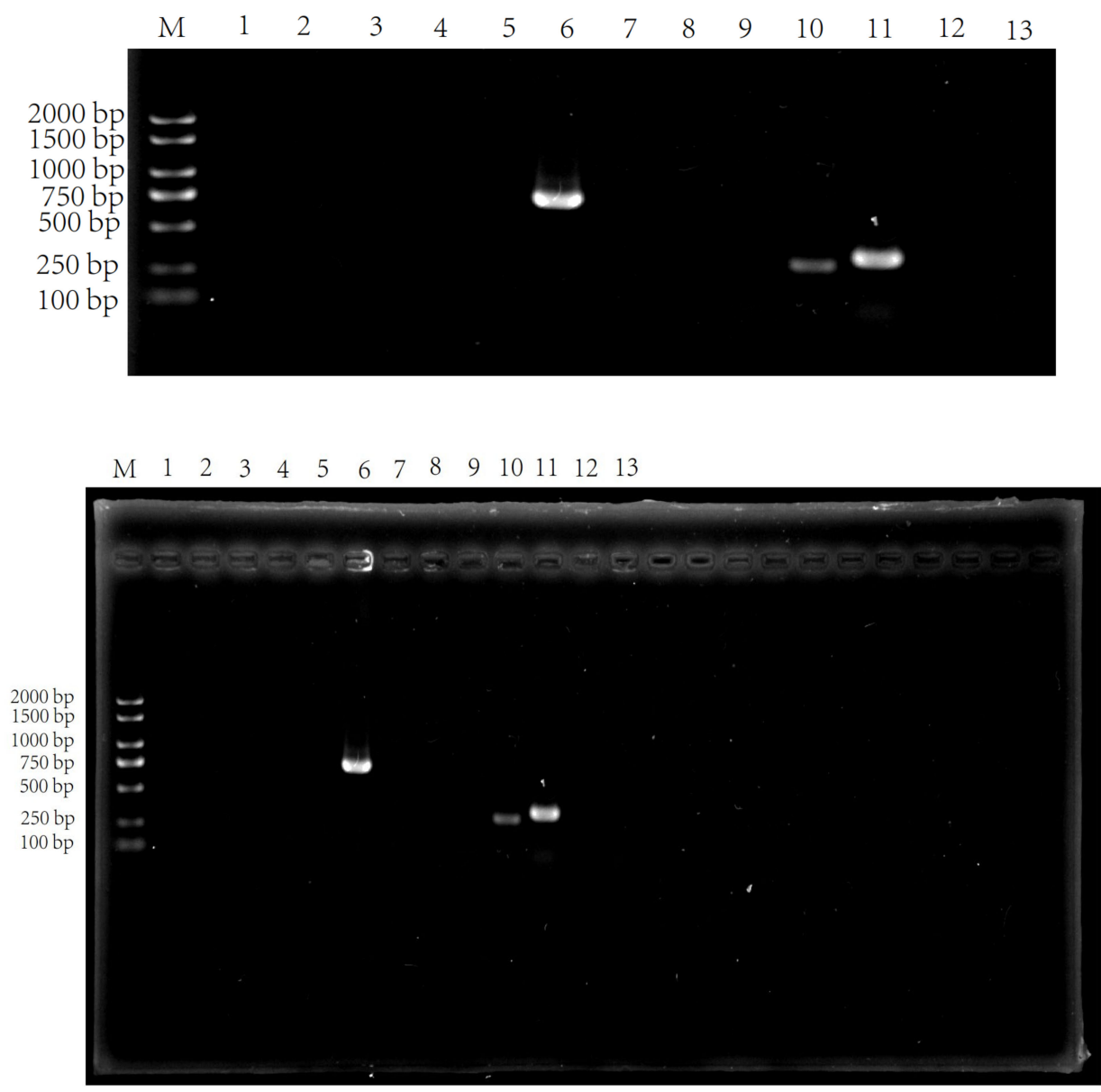

Figure 7. Agarose gel (1.5\%) electrophoresis of the PCR products of bacteriocin-related genes. Lane numbers represent bacteriocin-related genes as follows: M. DL2000 plus DNA Marker; 1. pln423; 2. $p \ln Q ; 3$. $p \ln N$; 4. PlnNC81F; 5. $p \ln X Y$; 6. plnW; 7. $p \ln J K ; 8$. plnA; 9. plnEF; 10. plnS; 11. ped; 12. pln; 13. ent.

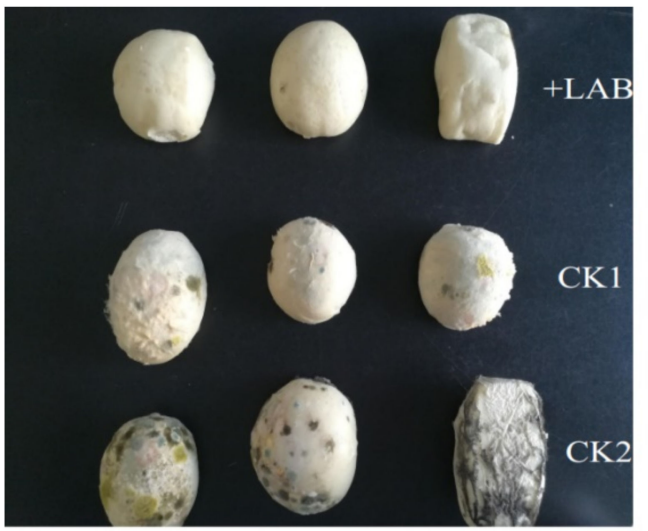

A

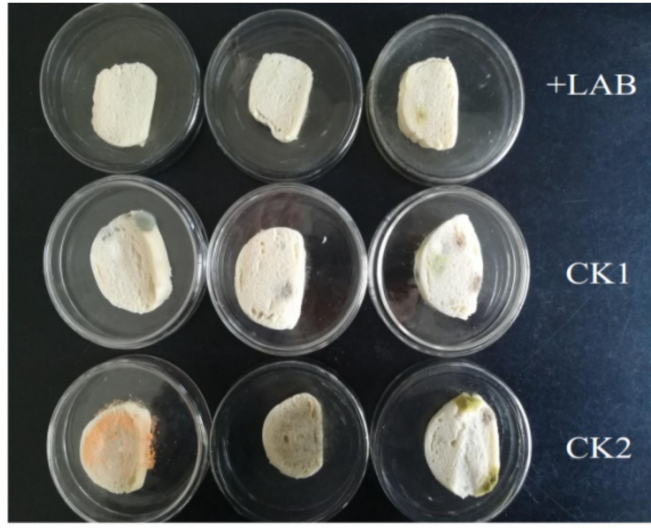

B

Figure 8. CSB in bag (A) and sliced (B) steamed bun placed for 6 days. CSB, Chinese steamed buns; LAB, lactic acid bacteria, Batter: $2 \mathrm{~mL}$ ZZUA493 suspension $+100 \mathrm{~mL}$ water $+100 \mathrm{~g}$ flour fermented at $30{ }^{\circ} \mathrm{C}$ for $14 \mathrm{~h}$; CK1, Batter: $2 \mathrm{~mL}$ water $+100 \mathrm{~mL}$ water $+100 \mathrm{~g}$ flour fermented at $30^{\circ} \mathrm{C}$ for $14 \mathrm{~h}$ control; CK2, Batter: $2 \mathrm{~mL}$ water $+100 \mathrm{~mL}$ water $+100 \mathrm{~g}$ flour unfermented control. 


\section{Conclusions}

In conclusion, we tested the antifungal activity of 359 strains of LAB in this study; among them, ZZUA493 had the highest activity against four different fungal species. There was good evidence that organic acids produced by ZZUA493 played an important role in fungal inhibition. The inclusion of sourdough fermentation with ZZUA493 in the preparation method for CSB approximately doubled their shelf life and improved both their flavor and texture. Therefore, ZZUA493 appears to have great potential as a natural, functional ingredient to markedly extend the shelf life of CSB.

Supplementary Materials: The following are available online at https://www.mdpi.com/article/10 .3390/foods11020195/s1, Figure S1: Universal primers for four species of fungi PCR amplification product agarose gel electrophoresis, Table S1: Specific PCR primers for genes involved in bacteriocin biosynthesis, Table S2: Antibacterial activity of ZZUA493, Figure S2: Effect of ZZUA493 on Angel yeast.

Author Contributions: Conceptualization, S.Z.; methodology, F.Y., X.H. and Y.W. (Yuan Wang); software, S.Z. and X.H.; validation, F.Y., X.H. and Y.W. (Yuan Wang); formal analysis, S.Z. and X.H.; investigation, X.H.; resources, F.Y., Y.W. (Yuan Wang) and X.F.; data curation, S.Z.; writingoriginal draft preparation, S.Z.; writing—review and editing, Y.W. (Yanping Wang); visualization, S.Z.; supervision, Y.W. (Yanping Wang); project administration, Y.W. (Yanping Wang); funding acquisition, Y.W. (Yanping Wang). All authors have read and agreed to the published version of the manuscript.

Funding: This research was funded by the National Natural Science Foundation of China (grant number 31772672).

Institutional Review Board Statement: Not applicable.

Informed Consent Statement: Not applicable.

Data Availability Statement: The ITS gene sequence of strains A, L, M and Q, used to support the findings of this study, have been deposited in the GenBank repository with accession numbers OM049201, OM049202, OM049222 and OM049221, respectively.

Conflicts of Interest: The authors declare no conflict of interest.

\section{References}

1. Pitt, J.I.; Hocking, A.D. Fungi and Food Spoilage; Springer: Boston, MA, USA, 2009; ISBN 978-0-387-92206-5.

2. Legan, J.D. Mould spoilage of bread: The problem and some solutions. Int. Biodeter. Biodegr. 1993, 32, 33-53. [CrossRef]

3. Moretti, A.; Logrieco, A.F.; Susca, A. Mycotoxins: An Underhand Food Problem. In Mycotoxigenic Fungi. Methods in Molecular Biology; Moretti, A., Susca, A., Eds.; Humana Press: New York, NY, USA, 2017; Volume 1542. [CrossRef]

4. Maftei, N.A.; Ramos-Villarroel, A.Y.; Nicolau, A.I.; Martín-Belloso, O.; Soliva-Fortuny, R. Influence of processing parameters on the pulsed-light inactivation of Penicillium expansum in apple juice. Food Control 2014, 41, 27-31. [CrossRef]

5. De Souza, V.R.; Popovic, V.; Warriner, K.; Koutchma, T. A comparative study on the inactivation of Penicillium expansum spores on apple using light emitting diodes at $277 \mathrm{~nm}$ and a low-pressure mercury lamp at $253.7 \mathrm{~nm}$. Food Control 2020, 110, 107039. [CrossRef]

6. Zhang, X.M.; Fu, M.R. Inhibitory effect of chlorine dioxide $\left(\mathrm{ClO}_{2}\right)$ fumigation on growth and patulin production and its mechanism in Penicillum expansum. LWT-Food Sci. Technol. 2018, 96, 335-343. [CrossRef]

7. He, C.; Zhang, Z.; Li, B.; Xu, Y.; Tian, S. Effect of natamycin on Botrytis cinerea and Penicillium expansum-Postharvest pathogens of grape berries and jujube fruit. Postharvest Biol. Technol. 2019, 151, 134-141. [CrossRef]

8. Siahmoshteh, F.; Hamidi-Esfahani, Z.; Spadaro, D.; Shams-Ghahfarokhi, M.; Razzaghi-Abyaneh, M. Unraveling the mode of antifungal action of Bacillus subtilis and Bacillus amyloliquefaciens as potential biocontrol agents against aflatoxigenic Aspergillus parasiticus. Food Control 2018, 89, 300-307. [CrossRef]

9. Sadiq, F.A.; Yan, B.W.; Tian, F.W.; Zhao, J.X.; Zhang, H.; Chen, W. Lactic Acid Bacteria as Antifungal and Anti-Mycotoxigenic Agents: A Comprehensive Review. Compr. Rev. Food Sci. Food Saf. 2019, 18, 1403-1436. [CrossRef]

10. Rodriguez Assaf, L.A.; Pedrozo, L.P.; Nally, M.C.; Pesce, V.M.; Toro, M.E.; Castellanos de Figueroa, L.I.; Vazquez, F. Use of yeasts from different environments for the control of Penicillium expansum on table grapes at storage temperature. Int. J. Food Microbiol. 2020, 320, 108520. [CrossRef]

11. Ngolong Ngea, G.L.; Yang, Q.; Castoria, R.; Zhang, X.; Routledge, M.N.; Zhang, H. Recent trends in detecting, controlling, and detoxifying of patulin mycotoxin using biotechnology methods. Compr. Rev. Food Sci. Food Saf. 2020, 19, 2447-2472. [CrossRef] 
12. Fabiszewska, A.U.; Zielinska, K.J.; Wrobel, B. Trends in designing microbial silage quality by biotechnological methods using lactic acid bacteria inoculants: A minireview. World J. Microb. Biot. 2019, 35, 76. [CrossRef]

13. Ammor, S.; Tauveron, G.; Dufour, E.; Chevallier, I. Antibacterial activity of lactic acid bacteria against spoilage and pathogenic bacteria isolated from the same meat small-scale facility: 2-Behaviour of pathogenic and spoilage bacteria in dual species biofilms including a bacteriocin-like-producing lactic acid bacteria. Food Control 2006, 17, 462-468. [CrossRef]

14. Corsetti, A.; Gobbetti, M.; Rossi, J.; Damiani, P. Antimould activity of sourdough lactic acid bacteria: Identification of a mixture of organic acids produced by Lactobacillus sanfrancisco CB1. Appl. Microbiol. Biot. 1998, 50, 253-256. [CrossRef] [PubMed]

15. Yang, E.J.; Chang, H.C. Purification of a new antifungal compound produced by Lactobacillus plantarum AF1 isolated from kimchi. Int. J. Food Microbiol. 2010, 139, 56-63. [CrossRef] [PubMed]

16. Lan, W.T.; Chen, Y.S.; Wu, H.C.; Yanagida, F. Bio-protective potential of lactic acid bacteria isolated from fermented wax gourd. Folia Microbiol. 2012, 57, 99-105. [CrossRef]

17. Muhialdin, B.J.; Hassan, Z.; Sadon, S.K. Antifungal Activity of Lactobacillus fermentum Te007, Pediococcus pentosaceus Te010, Lactobacillus pentosus G004, and L. paracasi D5 on Selected Foods. J. Food Sci. 2011, 76, M493-M499. [CrossRef]

18. Sadeghi, A.; Ebrahimi, M.; Mortazavi, S.A.; Abedfar, A. Application of the selected antifungal LAB isolate as a protective starter culture in pan whole-wheat sourdough bread. Food Control 2019, 95, 298-307. [CrossRef]

19. Zhu, Y.; Xiong, W.F.; Wang, L.F.; Ju, X.R. Insight into the effect of gluten-starch ratio on the properties of Chinese steamed bread (Mantou). Int. J. Biol. Macromol. 2020, 163, 1821-1827. [CrossRef]

20. Sim, S.Y.; Aziah, A.A.N.; Cheng, L.H. Characteristics of wheat dough and Chinese steamed bread added with sodium alginates or konjac glucomannan. Food Hydrocolloid 2011, 25, 951-957. [CrossRef]

21. Li, D.X.; Ni, K.K.; Pang, H.L.; Wang, Y.P.; Cai, Y.M.; Jin, Q.S. Identification and Antimicrobial Activity Detection of Lactic Acid Bacteria Isolated from Corn Stover Silage. Asian Austral. J. Anim. 2015, 28, 620-631. [CrossRef]

22. Gerez, C.L.; Torres, M.J.; de Valdez, G.F.; Rollan, G. Control of spoilage fungi by lactic acid bacteria. Biol. Control 2013, 64, $231-237$. [CrossRef]

23. Magnusson, J.; Schnürer, J. Lactobacillus coryniformis subsp. coryniformis Strain Si3 Produces a Broad-Spectrum Proteinaceous Antifungal Compound. Appl. Environ. Microb. 2001, 67, 1-5. [CrossRef]

24. Wang, H.; Yan, Y.; Wang, J.; Zhang, H.; Qi, W. Production and Characterization of Antifungal Compounds Produced by Lactobacillus plantarum IMAU10014. PLoS ONE 2012, 7, e29452. [CrossRef]

25. Guimarães, A.; Santiago, A.; Teixeira, J.A.; Venâncio, A.; Abrunhosa, L. Anti-aflatoxigenic effect of organic acids produced by Lactobacillus plantarum. Int. J. Food Microbiol. 2018, 264, 31-38. [CrossRef] [PubMed]

26. Doulgeraki, A.I.; Paraskevopoulos, N.; Nychas, G.J.E.; Panagou, E.Z. An in vitro study of Lactobacillus plantarum strains for the presence of plantaricin genes and their potential control of the table olive microbiota. Antonie Leeuwenhoek Int. J. Gen. 2013, 103, 821-832. [CrossRef] [PubMed]

27. Yi, H.X.; Zhang, L.W.; Tuo, Y.F.; Han, X.; Du, M. A novel method for rapid detection of class IIa bacteriocin-producing lactic acid bacteria. Food Control 2010, 21, 426-430. [CrossRef]

28. Leyva Salas, M.; Thierry, A.; Lemaître, M.; Gilles, G.; Harel-Oger, M.; Chatel, M.; Lê, S.; Mounier, J.; Valence, F.; Coton, E. Antifungal Activity of Lactic Acid Bacteria Combinations in Dairy Mimicking Models and Their Potential as Bioprotective Cultures in Pilot Scale Applications. Front. Microbiol. 2018, 9, 1787. [CrossRef] [PubMed]

29. El-Gendy, S.M.; Abdel-Galil, H.; Shahin, Y.; Hegazi, F.Z. Characteristics of Salt-Tolerant Lactic Acid Bacteria, in Particular Lactobacilli, Leuconostocs and Pediococci, Isolated from Salted Raw Milk. J. Food Prot. 1983, 46, 429-433. [CrossRef] [PubMed]

30. Juodeikiene, G.; Bartkiene, E.; Cernauskas, D.; Cizeikiene, D.; Zadeike, D.; Lele, V.; Bartkevics, V. Antifungal activity of lactic acid bacteria and their application for Fusarium mycotoxin reduction in malting wheat grains. LWT 2018, 89, 307-314. [CrossRef]

31. Lavermicocca, P.; Valerio, F.; Evidente, A.; Lazzaroni, S.; Corsetti, A.; Gobbetti, M. Purification and characterization of novel antifungal compounds from the sourdough Lactobacillus plantarum strain 21B. Appl. Environ. Microbiol. 2000, 66, 4084-4090. [CrossRef]

32. Guimarães, A.; Venancio, A.; Abrunhosa, L. Antifungal effect of organic acids from lactic acid bacteria on Penicillium nordicum Food Addit Contam Part A Chem Anal. Control Expo. Risk Assess. 2018, 35, 1803-1818. [CrossRef] [PubMed]

33. Fernandez, B.; Vimont, A.; Desfosses-Foucault, E.; Daga, M.; Arora, G.; Fliss, I. Antifungal activity of lactic and propionic acid bacteria and their potential as protective culture in cottage cheese. Food Control 2017, 78, 350-356. [CrossRef]

34. Prema, P.; Smila, D.; Palavesam, A.; Immanuel, G. Production and Characterization of an Antifungal Compound (3-Phenyllactic Acid) Produced by Lactobacillus plantarum Strain. Food Bioproc. Technol. 2010, 3, 379-386. [CrossRef]

35. Quattrini, M.; Bernardi, C.; Stuknyte, M.; Masotti, F.; Passera, A.; Ricci, G.; Vallone, L.; De Noni, I.; Brasca, M.; Fortina, M.G. Functional characterization of Lactobacillus plantarum ITEM 17215: A potential biocontrol agent of fungi with plant growth promoting traits, able to enhance the nutritional value of cereal products. Food Res. Int. 2018, 106, 936-944. [CrossRef] [PubMed]

36. Garcia-Gutierrez, E.; O'Connor, P.M.; Colquhoun, I.J.; Vior, N.M.; Rodriguez, J.M.; Mayer, M.J.; Cotter, P.D.; Narbad, A. Production of multiple bacteriocins, including the novel bacteriocin gassericin M, by Lactobacillus gasseri LM19, a strain isolated from human milk. Appl. Microbiol. Biot. 2020, 104, 3869-3884. [CrossRef] [PubMed]

37. Saugar, J.M.; Rodríguez-Hernández, M.J.; de la Torre, B.G.; Pachón-Ibañez, M.E.; Fernández-Reyes, M.; Andreu, D.; Pachón, J.; Rivas, L. Activity of cecropin A-melittin hybrid peptides against colistin-resistant clinical strains of Acinetobacter baumannii: Molecular basis for the differential mechanisms of action. Antimicrob. Agents Chemother. 2006, 50, 1251-1256. [CrossRef] 
38. Lee, D.G.; Shin, S.Y.; Kim, D.-H.; Seo, M.Y.; Kang, J.H.; Lee, Y.; Kim, K.L.; Hahm, K.-S. Antifungal mechanism of a cysteine-rich antimicrobial peptide, Ib-AMP1, from Impatiens balsamina against Candida albicans. Biotechnol. Lett. 1999, 21, 1047-1050. [CrossRef]

39. Cookson, A.L.; Noel, S.J.; Kelly, W.J.; Attwood, G.T. The use of PCR for the identification and characterisation of bacteriocin genes from bacterial strains isolated from rumen or caecal contents of cattle and sheep. FEMS Microbiol. Ecol. 2004, 48, 199-207. [CrossRef]

40. Macwana, S.J.; Muriana, P.M. A 'bacteriocin PCR array' for identification of bacteriocin-related structural genes in lactic acid bacteria. J. Microbiol. Meth. 2012, 88, 197-204. [CrossRef]

41. Devi, S.M.; Halami, P.M. Genetic Variation of pln Loci Among Probiotic Lactobacillus plantarum Group Strains with Antioxidant and Cholesterol-Lowering Ability. Probiotics Antimicro 2019, 11, 11-22. [CrossRef]

42. Guyot, J.-P. Cereal-based fermented foods in developing countries: Ancient foods for modern research. Int. J. Food Sci. Technol. 2012, 47, 1109-1114. [CrossRef]

43. Robert, H.; Gabriel, V.; Fontagné-Faucher, C. Biodiversity of lactic acid bacteria in French wheat sourdough as determined by molecular characterization using species-specific PCR. Int. J. Food Microbiol. 2009, 135, 53-59. [CrossRef] [PubMed]

44. Van Kranenburg, R.; Kleerebezem, M.; van Hylckama Vlieg, J.; Ursing, B.M.; Boekhorst, J.; Smit, B.A.; Ayad, E.H.E.; Smit, G.; Siezen, R.J. Flavour formation from amino acids by lactic acid bacteria: Predictions from genome sequence analysis. Int. Dairy J. 2002, 12, 111-121. [CrossRef] 